\title{
Occupational change and status mobility
}

\author{
The detrimental effects of unemployment and the loss of occupation specific human \\ capital
}

Arne Bethmann

Published online: 2 October 2013

(C) Institut für Arbeitsmarkt- und Berufsforschung 2013

\begin{abstract}
The impact of changes of the occupational field on the socio-economic status after unemployment has not received much attention in the literature so far. Due to a possible loss of occupation specific human capital the effects are assumed to be detrimental. This seems especially probable if the individual has attained specific human capital in the form of vocational training. A sample from the panel study "Labour Market and Social Security" (PASS) was used to analyse the occupational changes of unemployed individuals upon re-entry into the labour market. Compared to occupational changes from employment, changes in the unemployment group have stronger negative effects on the difference in socio-economic status between the last and the current job. The International Socio-Economic Index (ISEI) was used as the status measure. For unemployed individuals without vocational training no significant effect could be found, whereas those with training did incur substantial status losses. In conclusion the loss of occupation specific human capital due to changes of occupation does seem to be detrimental to the socio-economic situation of unemployed individuals after re-employment. This should be considered when applying strict labour market policies possibly pressuring individuals to change their occupation in order to take up employment more quickly.
\end{abstract}

Keywords Occupational change · Status mobility · Unemployment · Human capital

JEL Classification J62 $\cdot$ J44

A. Bethmann $(\varangle)$

Institute for Employment Research, Regensburger Straße 104, 90478 Nürnberg, Germany

e-mail: arne.bethmann@iab.de

\section{Berufswechsel und Statusmobilität. Die nachteiligen Effekte von Arbeitslosigkeit und der Verlust von berufsspezifischem Humankapital}

Zusammenfassung Der Einfluss von Wechseln des Berufsfeldes auf den sozioökonomischen Status nach Ende der Arbeitslosigkeit wurde in der Literatur bisher wenig berücksichtigt. Wegen des möglichen Verlustes von berufsspezifischem Humankapital wird vermutet, dass dieser Effekt negativ ist. Dies erscheint besonders wahrscheinlich, wenn das betroffene Individuum über spezifisches Humankapital in Form von Berufsbildung verfügt. Mit Hilfe des Panels „Arbeitsmarkt und Soziale Sicherung“ (PASS) wurden die Berufswechsel von arbeitslosen Individuen beim Wiedereinstieg in den Arbeitsmarkt untersucht. Im Vergleich mit Berufswechseln aus Erwerbstätigkeit haben Wechsel in der Arbeitslosengruppe einen stärkeren, negativen Effekt auf die Differenz im sozioökonomischen Status zwischen dem letzten und dem aktuellen Job. Der International SocioEconomic Index (ISEI) wurde dabei als Statusmaß verwendet. Für Arbeitslose ohne berufliche Bildung wurden keine signifikanten Effekte gefunden, wohingegen solche mit Berufsbildung deutliche Statusverluste hinnehmen mussten. Zusammenfassend scheint sich der Verlust von berufsspezifischem Humankapital durch den Wechsel des Berufes negativ auf die sozioökonomische Situation von arbeitslosen Personen nach der Wiederbeschäftigung auszuwirken. Dies sollte berücksichtigt werden, wenn im Rahmen von arbeitsmarktpolitischen Maßnahmen ein erhöhter Druck auf die Arbeitslosen ausgeübt wird ihren Beruf zu Wechseln, um schneller wieder in Arbeit zu kommen.

Schlüsselwörter Berufswechsel · Statusmobilität . Arbeitslosigkeit $\cdot$ Humankapital 


\section{Introduction}

For the change of an employed individual's occupation several authors report positive income effects (see Fitzenberger and Spitz-Oener 2004; Longhi and Brynin 2010; Nisic and Trübswetter 2012). The adverse effects of jobloss on an individual's income and socio-economic status on the other hand are also well known (see e.g. Gangl 2006; Kuhn 2002; Schmelzer 2012; Schmieder et al. 2010). The question remains whether the positive effects of occupational changes still apply when they happen in order to overcome a time of unemployment. The findings so far are rather scarce.

It is unclear whether a change of occupation leads to new opportunities possibly ameliorating the situation after unemployment or whether the opposite is true and an occupational change out of desperation further deteriorates the socio-economic consequences of spells of unemployment.

This process has to be understood in the context of the close interplay of the occupational labour market structure and the educational system. Considering the strong boundaries between occupational labour market segments brought about by a high level of standardisation of vocational education as e.g. in Germany, changes of occupation become problematic especially when individuals have attained a high level of formal education. Consequently the rates of job mobility are higher in less standardized educational systems (Allmendinger 1989; Schmelzer 2011).

The educational standardization defining occupations as bundles of specific skills can be viewed as a means of facilitating the labour market matching by reducing the transaction costs for the employer as well as the individual looking for a job (Abraham et al. 2011). At the same time this means a high risk of losing one's investment in vocational education to an occupational change as the specific skills and certificates might not be transferable to other occupations, leading to poorer job opportunities.

For unemployed individuals receiving unemployment or welfare benefits this might be especially severe as they might be forced by the employment agencies to take up employment even though the job does not match their qualifications. Gangl (2004b) shows that more generous welfare systems increase the chances of a good job match with less detrimental effects on the socio-economic outcome. In Germany a stricter welfare legislation was introduced in 2005 demanding benefits recipients to take up any employment offered by the employment agency even though it is not in the former field of occupation ( $\$ 10$ Social Code II).

The article will therefore address the following research questions:

- What is the impact of occupational changes on the socioeconomic outcomes on re-employment following a spell of unemployment?
- In how far does vocational training mediate this process?

In order to empirically investigate these questions a sample of both employed and unemployed individuals from the panel study "Labour Market and Social Security" (PASS) conducted by the German Institute for Employment Research is used. Changes of occupation are measured using the concept by Matthes et al. (2008) clustering occupations into segments with high transferability of skills. The socioeconomic outcome is measured via the International SocioEconomic Index (ISEI). This is a latent measure for the transmission of education to income characterising each particular occupation (Ganzeboom et al. 1992).

The next section will discuss the linkage of the occupational structuring of labour markets and aspects of human capital and signalling theories in order to build a theoretical framework for the analysis of determinants and outcomes of an individual's change of the occupational field upon reentry into the labour market. The dataset and the statistical methods employed in the analysis will then be introduced in the following section. The fourth section provides a comprehensive account of the results and is followed by summarizing and concluding remarks in the last section.

\section{Theory}

Starting as early as in the writings of Emile Durkheim and Max Weber the concept of an occupation was considered a central aspect of the social positioning of individuals and the societal division of labour (for an overview of the development of occupational sociology see e.g. Demszky von der Hagen and Voß 2010; Kurtz 2002). It was used as a theoretical basis for the analysis of social structure as well as the relation of the individual and society for quite some time.

Since at least the 1980s the utility of occupation as an analytical category was increasingly called into question. Due to the accelerated change of skill requirements vocational training is assumed to become obsolete more quickly, leading to the necessity of life-long adaptation of an individual's skill set to the requirements of the labour market (Pongratz and Voß 2004). Although plausible in theory critics and proponents of these notions agree that it is unclear how fast the process develops and that there is still a need for visible skill sets in order to facilitate the matching process on the labour market (Demszky von der Hagen and Voß 2010; Kupka 2005).

\subsection{Occupational structuring of the labour market}

Commonly the labour market is assumed to be a two-sided matching market. On the supply side there is the applicant featuring a specific set of skills and looking for a new job. 
While on the demand side the employer is looking to fill vacancies with specific skill requirements. If the applicants expectations regarding working conditions, wage etc. are met and the employer has sufficient confidence in the applicant's productivity, the recruitment will take place (see e.g. Gangl 2004a; Halaby 1988; Hinz and Abraham 2008; Logan 1996). The standardisation of education in the form of specific bundles of skills-e.g. vocational certificates for specific occupations - can be assumed to lower the transaction costs for the employer as well as the individual to be employed and to lead to better matches (Abraham et al. 2011).

Following Becker (1993) it can be assumed that an individual's productivity is increased by the investment in general and specific forms of human capital, e.g. schooling or vocational training. The productivity is remunerated by the employer and thus impacts directly on an individual's wage and socio-economic situation. In deciding what specific training to invest in the individual can be guided by institutionally regulated qualifications like occupational certificates, since they provide information about future job opportunities and reduce insecurity. These certificates then function as a signal of productivity to a future employer (see Spence 2002), as they define the set of skills the job applicant has and hint at the probable match for the specific vacancy.

While facilitating the matching process on the labour market a high level of standardisation also leads to strong occupational segmentation of the labour market (Allmendinger 1989; Soskice 1999). On the macro level the entry barriers for specific occupational segments of the labour market get higher, inhibiting fluctuation between the segments and resulting in lower rates of job mobility when compared to nations with weaker occupational institutions (DiPrete et al. 1997; Longhi and Brynin 2010; Nisic and Trübswetter 2012).

On the individual level the reasons for the reluctance to change the occupation after investing in specific occupational certificates are twofold. Firstly individuals might face an actual devaluation of their specific human capital to the degree that it is not transferable to the new job. Secondly the potential employer does not receive a strong signal of productivity as the applicant would be lacking a proper educational certificate documenting the appropriate skills for the new occupation and hence hire the applicant only for jobs where less complex skill sets are required. Both aspects would impair the job opportunities and consequently the individual socio-economic situation.

The empirical evidence so far shows that in many cases individuals actually benefit from a change of occupation (Fitzenberger and Spitz-Oener 2004; Longhi and Brynin 2010; Nisic and Trübswetter 2012). Positive effects might be expected when individuals were in a job that did not match their specific qualifications before the change and in a well matching job afterwards. These cases would then be able to use their full productive potential in the latter job and earn the appropriate salary. Nisic and Trübswetter (2012) show that this is mostly due to individuals changing their occupation on a voluntary basis and that involuntary occupational changes still lead to income losses.

\subsection{Socio-economic outcomes of unemployment}

The specific human capital of an individual is threatened by unemployment due to deterioration over time off the job (Pissarides 1992) as well as instant devaluation via an increased pressure to accept a job in a different industrial sector or occupation to which it cannot be transferred (Gangl 2006). These effects are confirmed by e.g. Burda and Mertens (2001) who report high levels of industrial and occupational mobility of displaced workers in Germany connected to earnings losses. Fallick (1996) finds similar results for the USA. Gregory and Jukes (2001) and Bender et al. (2002) conclude that especially longer durations of unemployment have negative effects on earnings.

Unemployment experiences can also have a distinct effect on the prospective employer, as it might be received as a strong negative signal suggesting low productivity of the respective applicant (Gibbons and Katz 1991; Lockwood 1991). In comparing laid-off workers with those losing their job to plant closing Gibbons and Katz (1991) find lower wages after re-employment and longer spells of unemployment for the first group. They suggest that in the plant closing case the negative signal of the unemployment incidence is not as strong. Bender et al. (2002) arrive at similar conclusions.

\subsection{Occupational change, unemployment and human capital}

Although the socio-economic effects of occupational changes as well as unemployment have received substantial scientific attention, the interrelation of both is not as clear. While occupational changes cannot be considered negative in all cases, especially in conjunction with unemployment experiences they could possibly have severe negative effects on an individual's socio-economic situation after re-employment. In cases of prior unemployment an occupational change is far more likely to be involuntary than when changing directly from one job to the other, possibly leading to a more pronounced negative impact on the socioeconomic situation. So far studies comparing occupational changes out of employment with those out of unemployment are lacking.

In countries with highly standardised educational systems the vocational certificates that restrict access to occupational labour market segments are particularly valuable. When changing the occupational field the investments 
in theses certificates are in jeopardy. Therefore individuals would not likely change the occupational field voluntarily when they have attained higher levels of vocational education. When unemployed they might be forced to do so in order to get employment, likely incurring a deterioration of their socio-economic situation when compared to their last employment. As discussed this would be expected due to the instantaneous devaluation of the occupation specific human capital and the lack of occupational certificates as a signal of productivity to the new employer. Individuals without formal vocational qualification on the other hand might not be as susceptible to negative consequences of occupational changes, since there is not as much occupation specific human capital that could be lost.

Apart from the unemployment situation as such the receipt of state transfers could affect the impact of occupational changes on an individual's job opportunities. Since the introduction of a new welfare legislation in Germany in 2005 (Social Code II), the system of unemployment benefits consists of two parts. The Unemployment Benefit I (UB I) is an insurance based benefit substituting 60 percent of the income in the last job. After the entitlements run out after approximately 12 months or if an individual does not qualify for entitlements the Unemployment Benefit II (UB II) receipt might set in. These are means-tested minimal welfare benefits for households in need of financial support. Especially under the conditions of the UB II the main legislative objective is the quick reintegration into the labour market. Therefore the focus lies on activation of benefit recipients to take up work (Eichhorst et al. 2010). With respect to the change of occupation the law explicitly states that job offers are reasonable even if they are not in the occupational field the unemployed individual has prior experience in or attained vocational certificates for ( $\$ 10$ Social Code II). Failure to accept these job offers can lead to financial sanctions. In conclusion the receipt of state transfers can be considered an additional source of pressure to accept a change of occupation as the phase of unemployment endures.

\subsection{Main Hypotheses}

The impact of occupational changes on an individual's job opportunities when compared to individuals re-employed in the same occupation is likely to depend on the employment status prior to the change. While occupational changes out of employment will often be conducted voluntarily, those that follow a phase of unemployment will to a larger proportion be involuntary. Since involuntary occupational changes increase the risk of employment in a job where occupation specific human capital and vocational certificates cannot be utilized, chances are that the former unemployed individuals changing their occupation would incur severe losses in socio-economic status when compared to those who were employed before switching their occupation. This leads to the following hypotheses:

Hypothesis 1: Occupational changes among unemployed individuals lead to a decline in socio-economic status upon re-entry into the labour market.

Hypothesis 2: Changes of occupation have a stronger negative impact for individuals who were previously unemployed, than for those who were employed before the change.

Short periods of unemployment might not be as pressuring as longer durations, since the institutional pressure increases with time while the socio-economic situation gradually deteriorates. This should in turn lead to an increasing proportion of involuntary occupational changes with negative outcomes for the following job.

Hypothesis 3: The negative effects of occupational changes on socio-economic status mobility increase with the duration of unemployment.

Higher levels of vocational education constitute higher investments in occupation specific human capital, which is unlikely to be risked voluntarily. With the rising pressure due to unemployment these individuals might nevertheless be forced to accept a negative change of occupation.

Hypothesis 4: The negative effects of occupational changes on status mobility among unemployed individuals with vocational training are stronger than among employed individuals with vocational training.

Hypothesis 5: Higher levels of vocational training yield stronger negative effects of occupational changes on the socio-economic status under conditions of unemployment than lower levels.

\section{Data and methods}

The dataset for the analysis consists of the first five waves of the panel study "Labour Market and Social Security" which is conducted annually by the German Institute for Employment Research (IAB) since 2006. The survey comprises interviews of 12,000 to 19,000 respondents in each wave (Berg et al. 2012). PASS is intended to provide a database to analyse the dynamics of welfare benefits receipt and the situation of the recipients after the introduction of the new German welfare legislation in 2005. It consists of two sub samples: One drawn from the pool of Unemployment Benefit II recipients and the other from the general population. This sample structure yields a sufficient number of unemployed individuals relevant for the analysis in this article as well as employed individuals as a reference group. The questionnaires comprise items concerned with the situation of the 
particular household (e.g. benefits receipt, household structure, standard of living), as well as questions for each individual household member (e.g. employment histories, education, migration background, attitudes towards work). As PASS is a household study all individuals aged 15 years and above living in a particular household are surveyed. ${ }^{1}$

In order to operationalize occupational changes the concept of "Berufssegmente" (occupational segments) by Matthes et al. (2008) was used. These segments were developed by clustering the occupations in the German classification of occupations from 1988 ("Klassifikation der Berufe 1988 ", KldB 88) regarding the transferability of skills. The measure of transferability is regularly assessed manually by the Federal Employment Agency based on qualitative descriptions of necessary skills for specific occupations. It is used by the employment agencies to suggest alternative occupations to unemployed individuals. Matthes et al. (2008) arrive at a classification of 21 occupational segments (see the respective covariates in Table 3 ) which have a higher discriminatory power than the original classification. Although only applicable to Germany the occupational segments should give more precise estimates of mobility, by reducing the number of spurious changes and focusing more on the changes between occupational fields which come with a loss of usable specific human capital. For the analysis a change of occupation is defined as the occupational segment of the current employment not matching the information about the last employment.

The International Socio-Economic Index of Occupational Status (ISEI) is used to assess the outcome of occupational changes in the analysis. It is commonly used for the investigation of status mobility (see e.g. Blossfeld and Hofmeister 2006; Blossfeld et al. 2006; Gangl 2004a; Schmelzer 2011). Developed as a continuous measure of socio-economic stratification, the ISEI measures the relationship between an individual's income and education via the occupation (Ganzeboom et al. 1992). An optimal scaling algorithm was used to estimate the particular occupation's "relative earning power", maximising the indirect effect of education on income through occupation. This results in a specific score for 271 distinct categories of the International Standard Classification of Occupations (ISCO 88). The ISEI ranges from 16 to 90 points, where 16 indicates the lowest possible socio-economic level and 90 the highest. The reasons why the ISEI score was used rather than income itself are twofold. Firstly, for unemployed individuals the income of the last job before unemployment is often not known as it is not surveyed retrospectively. Secondly, as income can be very volatile even within one job the ISEI score seems to provide a more stable approximation of the socio-economic

${ }^{1}$ Further information on PASS can be found at: http://www.iab.de/ PASS. outcome. The outcome variable for the analysis of socioeconomic mobility in this article is constructed as the difference between the ISEI score of the last and the current employment. In order to alleviate floor and ceiling effects individuals with the highest or lowest possible ISEI score (90 and 16 points on the ISEI scale respectively) in their last employment were excluded from the analysis.

For the employment status in the wave prior to the current employment four categories are used. The first category defines individuals who were employed or self-employed ${ }^{2}$ in the previous wave as well and serve as a reference group. In accordance with the theoretical considerations unemployment has to be further differentiated. Based on the definition of long-term unemployment found in German law ( $\$ 18$ Social Code III) and widely used in the official statistics, one group includes those unemployed for a maximum of 12 months or less at the time of the last interview, representing short-term unemployment. The other group comprises individuals who were unemployed for more than 12 month. ${ }^{3}$ A last category is used for respondents that had any other employment status, like those on parental leave, students, housewives/-husbands etc.

Vocational education is used as the primary measure for occupation specific human capital. In the German educational system non-tertiary vocational training like apprenticeships and courses at vocational schools play an important role in addition to tertiary education at technical colleges and universities. In contrast to the latter non-tertiary vocational training regularly requires less prior schooling, only $9-10$ years compared to $12-13$ years for tertiary education. The indicator for vocational education is coded into three levels: no vocational training; basic (e.g. apprenticeships) and high (degrees from technical colleges or universities etc.).

The household structure is included as a control to account for different outcomes for men and women with and without partner or children. The level of schooling is also controlled for as it could be considered a form of more general human capital easily transferable to different occupations and possibly alleviating negative effects of occupational changes. The migration background is included in order to control for possible language problems, the missing accreditation of foreign educational certificates or discrimination. Since the labour market in the eastern and western parts of Germany still exhibits structural differences an indicator for residence in east or west is used in the analysis. Age might also impact on the outcomes of occupational

\footnotetext{
${ }^{2}$ Sensitivity analyses on a sample excluding self-employed individuals were conducted, but showed no substantial differences.

${ }^{3}$ These categories must be considered an approximation of the length of unemployment, since they do not account for the precise point in time between the two panel waves when employment was taken up.
} 
Table 1 Descriptive statistics for occupational changes by employment status and vocational training

\begin{tabular}{|c|c|c|c|c|c|c|c|c|c|}
\hline & \multicolumn{3}{|c|}{ Change of occupational segment } & \multicolumn{3}{|c|}{ No change } & \multicolumn{3}{|l|}{ Total } \\
\hline & $\%$ & $N$ & $\varnothing$ ISEI diff. & $\%$ & $N$ & $\varnothing$ ISEI diff. & $\%$ & $N$ & $\varnothing$ ISEI diff \\
\hline \multicolumn{10}{|l|}{ Employment status in last panel wave } \\
\hline Employed & 5.38 & 504 & -0.081 & 94.62 & 8,860 & 0.058 & 100.00 & 9,364 & 0.051 \\
\hline Unemployed for 12 months or less & 54.23 & 173 & -1.647 & 45.77 & 146 & 0.356 & 100.00 & 319 & -0.730 \\
\hline Unemployed for more than 12 months & 69.44 & 334 & -3.533 & 30.56 & 147 & -0.571 & 100.00 & 481 & -2.628 \\
\hline Other status & 45.85 & 232 & -0.319 & 54.15 & 274 & 0.573 & 100.00 & 506 & 0.164 \\
\hline \multicolumn{10}{|l|}{ Level of vocational training } \\
\hline None & 18.16 & 219 & -0.776 & 81.84 & 987 & -0.004 & 100.00 & 1,206 & -0.144 \\
\hline Basic (apprenticeship etc.) & 11.46 & 770 & -1.791 & 88.54 & 5,950 & 0.026 & 100.00 & 6,720 & -0.182 \\
\hline $\begin{array}{l}\text { High (degree from technical college or } \\
\text { university etc.) }\end{array}$ & 9.26 & 254 & -0.112 & 90.74 & 2,490 & 0.198 & 100.00 & 2,744 & 0.168 \\
\hline Total & 11.65 & 1,243 & -1.271 & 88.35 & 9,427 & 0.068 & 100.00 & 10,670 & -0.088 \\
\hline
\end{tabular}

Source: PASS Scientific Use File 2006-2011 V1, own calculations

changes since re-employment becomes more difficult after a certain age and occupational changes might mean stronger adverse career effects. Therefore age is included as a linear and quadratic term. In order to control for the occupational segments at the last employment, all segments are included as dummy variables, leaving out "office clerks" as the reference category. As the data span the time from the end of 2006 to 2011 an indicator for the current wave is also included as a way to capture temporal effects.

Specific effects of a change in occupation for different subgroups where estimated by including several interaction terms. The employment status, level of vocational training, and level of schooling were interacted with the indicator for an occupational change. Three level interactions were included for employment status with level of vocational training and with occupational change, as well as employment status with level of schooling and with occupational change. Also age was interacted with occupational change in order to control for a varying effect of a change in occupation at different stages in the life course.

For the multivariate regression analysis a linear random intercept model as formulated in Eq. (1) is estimated using the ISEI difference between current and last employment $y_{i j}-y_{i-1, j}$ as the dependent variable (see Allison 1990). $j$ is an indicator for the individual and $i$ indicates the point in time of the specific information for this individual. In using this change score the impact of unobserved heterogeneity on the estimates can be reduced since the individual base line of the ISEI score is implicitly controlled for. $\boldsymbol{x}_{i j}$ represents the vector of time-constant as well as time-varying covariates. The respective regression coefficients are given by the vector $\boldsymbol{\beta}$.

$y_{i j}-y_{i-1, j}=\boldsymbol{\beta} \boldsymbol{x}_{i j}+v_{j}+\epsilon_{i j}$

The individual random intercept $v_{j}$ allows for further control of unobserved heterogeneity on the person level if individuals contribute more than one observation to the estimation sample (see e.g. Skrondal and Rabe-Hesketh 2004). The observation specific residual is given by $\epsilon_{i j} . v_{j}$ and $\epsilon_{i j}$ are assumed to be normally distributed with means of 0 and variances $\sigma_{v}$ and $\sigma_{\epsilon}$. Since the variances of $y$ and the relevant covariates within an individual are rather small in the sample due to the shortness of the panel a random intercept specification is used, assuming $v_{j}$ to be uncorrelated with the covariates. ${ }^{4}$

\section{Results}

\subsection{Descriptives}

On average 11.6 percent of the cases in the analysis sample change the occupational field from one wave to the next in comparison to the last employment (see Table 1). This relatively high number is due to changes out of unemployment. In these cases the average rate of occupational changes is 54.2 percent in the short-term and 69.4 percent in the longterm group. The 5.4 percent rate of occupational mobility among employed individuals is more in line with the 3.4 percent reported by Nisic and Trübswetter (2012) and Longhi

\footnotetext{
${ }^{4}$ Although a Hausman test, comparing the model estimates to those of a fixed effects model, showed significant differences, the random intercept specification is used due to its higer efficiency.
} 
Table 2 Average marginal effects of occupational change in subgroups

\begin{tabular}{|c|c|c|c|c|}
\hline & Level of vocational training & Average marginal effect & $95 \%$ CI lower bound & $95 \%$ CI upper bound \\
\hline \multicolumn{5}{|l|}{ Employment status in last panel wave } \\
\hline \multirow[t]{4}{*}{ Employed } & average & -0.502 & -1.023 & 0.019 \\
\hline & none & -2.183 & -3.561 & -0.805 \\
\hline & basic & 0.586 & -0.112 & 1.283 \\
\hline & high & -2.432 & -3.556 & -1.308 \\
\hline \multirow[t]{4}{*}{ Unemployed for 12 months or less } & average & -2.655 & -4.029 & -1.282 \\
\hline & none & -0.381 & -3.573 & 2.810 \\
\hline & basic & -2.156 & -3.773 & -0.539 \\
\hline & high & -4.899 & -8.262 & -1.537 \\
\hline \multirow[t]{4}{*}{ Unemployed for more than 12 months } & average & -3.143 & -4.342 & -1.945 \\
\hline & none & 0.883 & -1.959 & 3.724 \\
\hline & basic & -1.479 & -2.956 & -0.003 \\
\hline & high & -9.036 & -11.785 & -6.287 \\
\hline \multirow[t]{4}{*}{ Other status } & average & -1.135 & -2.195 & -0.075 \\
\hline & none & 0.271 & -2.288 & 2.831 \\
\hline & basic & -3.045 & -4.368 & -1.722 \\
\hline & high & 2.942 & 0.633 & 5.250 \\
\hline
\end{tabular}

Average marginal effects based on full regression model in Table 3

Source: PASS Scientific Use File 2006-2011 V1, own calculations

and Brynin (2010). The descriptive statistics for the occupational mobility rates within the different levels of vocational training suggest that occupation specific human capital might indeed inhibit changes.

Turning to the changes in socio-economic status occupational changes seem to have no substantial effect for individuals already being employed in the last wave. For the unemployed on the other hand occupational changes appear to have a negative influence, even more so for the long-term unemployed. When looking at the different groups of vocational attainment individuals without occupation specific human capital seem to lose socio-economic status due to an occupational change, whereas the effect for basic vocational training appears to be even stronger negative. Still negative the effect for higher levels of vocational training is the smallest.

\subsection{Multivariate analysis}

Table 2 summarises the regression estimates for the effects of occupational changes within the different employment status and vocational training groups. Average marginal effects ${ }^{5}$ are used to facilitate the interpretation of the results

\footnotetext{
${ }^{5}$ The estimation was done using the delta method implemented in STATA's "margins" command after running the full regression model. Do-Files can be obtained from the author.
}

for the three-way-interaction between these variables (see Table 3 in the Appendix for the full regression model).

As assumed unemployed individuals incur a loss in socio-economic status when changing the occupational segment upon re-entry into the labour market. This is true for long-term as well as short-term unemployment and thereby supports hypothesis 1 . A statistically significant decline of 3.143 ISEI points is estimated in the former and 2.655 points in the latter group.

Also these effects differ strongly from the impact of an occupational change among those individuals who were employed in the last wave. For this group the model estimates yield no substantial effect. Although the point estimate is slightly negative it is not statistically significant. Regarding hypothesis 2 the results show that the effects in the unemployment groups are significantly stronger than the one for employment, since the 95 percent confidence intervals are not overlapping. It can be concluded that changes of occupation are indeed more detrimental when done in order to end unemployment.

The duration of unemployment as operationalized here does not seem to further enhance the negative effect of an occupational change on the socio-economic outcome. At least there is no strong evidence for hypothesis 3 as the confidence intervals for the effect in both unemployment duration groups do overlap to a large extend. While the points estimates differ only slightly in the direction of 
a stronger negative effect in the long-term unemployment group.

Focusing on the influence of vocational training on the effects of occupational mobility the results are less clear. Employed individuals lose socio-economic status when changing the occupational segment, given that they have no vocational training at all or high levels of it. There is no apparent effect for those with basic vocational training. In comparing effects on the different levels of vocational education between the employed and the two unemployed groups some evidence for hypothesis 4 can be found. Looking at basic vocational training the effect of an occupational change is significantly more negative in the short-term unemployment group than for employed individuals. This cannot be confirmed for long-term unemployment. While the effect for those with basic vocational training in this group is significantly negative and not so among employed individuals the effects do not differ on a statistically significant level. For higher levels of vocational education we find the opposite situation. The effect among long-term unemployed is pronouncedly stronger than for those individuals employed in the last wave. If the latter are compared to short-term unemployed higher levels of vocational training do not seem to further aggravate the socio-economic status outcome of occupational mobility.

For the two unemployment groups the point estimates for the effect of occupational mobility on the different levels of vocational education suggest increasing severity of status loss with rising investments in vocational training. When looking at the precision of the estimates it becomes obvious that the differences between the effects for different levels of training within the short-term unemployment group are not statistically significant and cannot support hypothesis 5 for this group. Among the long-term unemployed the effect for individuals with high levels of vocational training is significantly more pronounced than for those with basic or no training. This would give at least partial support for hypothesis 5 .

\section{Conclusion}

It was argued that under conditions of unemployment changes of the occupational field are likely to lead to losses of socio-economic status. The pressure to re-enter the labour market could force an individual to take up employment even though the prior occupation specific human capital could not be transferred to the new occupational domain and therefore lead to poorer job opportunities. It was further assumed that the detrimental effect of occupational changes would be more severe the higher the individual level of vocational training was.
The multivariate analyses show that occupational changes do indeed impact negatively on the socio-economic status in the new job when the change was made by individuals who were unemployed in the last panel wave. The effect is significantly stronger than when a change occurred for individuals being employed in the last wave. While the evidence is less strong it also suggests that the loss of occupation specific human capital is more problematic for individuals with higher levels of vocational education.

These findings should be considered when approaching unemployed individuals with strict reintegration policies. Although they might help to reduce public expenditure on social welfare and get people to overcome unemployment more quickly they might also come at the cost of harming the socio-economic welfare after re-employment. The analyses at hand do suggest so at least for the situation right after the start of the new job. They support the assessment that it might be beneficial to allow unemployed individuals to look for a well matching job even if this means a longer dependency on state transfers (see e.g. Gangl 2004b). A loss of occupation specific human capital should be avoided in order to protect the individual from a decline in socio-economic status. This seems also sensible when considering the looming shortage of qualified workers in certain fields of the German economy.

To enlarge upon the effects of occupational changes for unemployed individuals, future studies should focus on the long-term effects which could not be assessed here. This would allow for more far-reaching policy advice as it would enable analyses whether the new employment-although worse than the last one-can be considered a stepping stone on the way to improved socio-economic welfare or whether it is just another step in the "no pay, low pay cycle" (see Stewart 2007; Uhlendorff 2006). Also the presented analyses are not able to distinguish between the unemployed individual's own initiative and the institutional pressure to accept a change of occupation. While there is information on the receipt of different unemployment benefits in the data, the case numbers would have been too small to further differentiate by these criteria. More profound conclusions must be postponed to future investigations.

\section{Executive summary}

For the change of an employed individual's occupation several authors report positive income effects. The adverse effects of job-loss on an individual's income and socioeconomic status on the other hand are also well known. The question remains whether the positive effects of occupational changes still apply when they happen in order to overcome a time of unemployment. The findings so far are rather scarce. It is unclear whether a change of occupation 
leads to new opportunities possibly ameliorating the situation after unemployment or whether the opposite is true and an occupational change out of desperation further deteriorates the socio-economic consequences of spells of unemployment.

This process has to be understood in the context of the close interplay of the occupational labour market structure and the educational system. Considering the strong boundaries between occupational labour market segments brought about by a high level of standardisation of vocational education as e.g. in Germany, changes of occupation become problematic especially when individuals have attained a high level of formal education. Consequently the rates of job mobility are higher in less standardized educational systems. The educational standardization defining occupations as bundles of specific skills can be viewed as a means of facilitating the labour market matching by reducing the transaction costs for the employer as well as the individual looking for a job. At the same time this means a high risk of losing one's investment in vocational education to an occupational change as the specific skills and certificates might not be transferable to other occupations, leading to poorer job opportunities.

For unemployed individuals receiving unemployment or welfare benefits this might be especially severe as they might be forced by the employment agencies to take up employment even though the job does not match their qualifications. Research shows that more generous welfare systems increase the chances of a good job match with less detrimental effects on the socio-economic outcome. In Germany a stricter welfare legislation was introduced in 2005 demanding benefits recipients to take up any employment offered by the employment agency even though it is not in the former field of occupation ( $\$ 10$ Social Code II).

The article therefore addresses the following research questions:

- What is the impact of occupational changes on the socioeconomic outcomes on re-employment following a spell of unemployment?

- In how far does vocational training mediate this process?

In order to empirically investigate these questions a sample of both employed and unemployed individuals from the panel study "Labour Market and Social Security" (PASS) conducted by the German Institute for Employment Research is used. Changes of occupation are measured using a concept that clusters occupations into segments with high transferability of skills. The socio-economic outcome is measured via the International Socio-Economic Index (ISEI). This is a latent measure for the transmission of education to income characterising each particular occupation.
It is argued that under conditions of unemployment changes of the occupational field are likely to lead to losses of socio-economic status. The pressure to re-enter the labour market could force an individual to take up employment even though the prior occupation specific human capital could not be transferred to the new occupational domain and therefore lead to poorer job opportunities. It is further assumed that the detrimental effect of occupational changes would be more severe the higher the individual level of vocational training is.

The multivariate analyses show that occupational changes do indeed impact negatively on the socio-economic status in the new job when the change was made by individuals who were unemployed in the last panel wave. The effect is significantly stronger than when a change occurred for individuals being employed in the last wave. While the evidence is less strong it also suggests that the loss of occupation specific human capital is more problematic for individuals with higher levels of vocational education.

These findings should be considered when approaching unemployed individuals with strict reintegration policies. Although they might help to reduce public expenditure on social welfare and get people to overcome unemployment more quickly they might also come at the cost of harming the socio-economic welfare after re-employment. The analyses at hand do suggest so at least for the situation right after the start of the new job. They support the assessment that it might be beneficial to allow unemployed individuals to look for a well matching job even if this means a longer dependency on state transfers. A loss of occupation specific human capital should be avoided in order to protect the individual from a decline in socio-economic status. This seems also sensible when considering the looming shortage of qualified workers in certain fields of the German economy.

\section{Kurzfassung}

Für den Berufswechsel von beschäftigten Personen berichten mehrere Autoren positive Einkommenseffekte. Die nachteiligen Effekte des Arbeitsplatzverlustes für das Einkommen und den sozioökonomischen Status sind ebenfalls bekannt. Es bleibt die Frage, ob die positiven Effekte von Berufswechseln auch dann Bestand haben, wenn sie geschehen um Arbeitslosigkeit zu überwinden. Bisher gibt es dazu einen Mangel an Befunden. Es ist unklar, ob ein Berufswechsel neue Chancen eröffnet, die die Situation nach der Arbeitslosigkeit potentiell verbessern oder ob das Gegenteil zutrifft und ein Berufswechsel in dieser Situation die soziökonomischen Folgen der Arbeitslosigkeit weiter verschlimmert. 
Dieser Prozess muss im Kontext des engen Zusammenspiels von beruflichen Arbeitsmarktstrukturen und dem Bildungssystem verstanden werden. Betrachtet man die starken Barrieren zwischen den beruflichen Arbeitsmarktsegmenten, wie sie z. B. in Deutschland durch einen hohen Grad an Standardisierung der beruflichen Bildung erzeugt werden, erscheinen Berufswechsel vor allem dann problematisch, wenn die betroffenen ein hohes $\mathrm{Ma} \beta$ an formaler Bildung erworben haben. Dementsprechend sind die Raten von Jobwechseln in weniger standardisierten Bildungssystemen höher. Die Bildungsstandardisierung, die Berufe als Bündel von spezifischen Fähigkeiten definiert, kann als ein Weg verstanden werden die Passung am Arbeitsmarkt zu erhöhen, in dem sowohl für den Arbeitgeber als auch für denjenigen der nach Arbeit sucht die Transaktionskosten reduziert werden. Gleichzeitig bedeutet dies, dass ein hohes Risiko besteht durch einen Berufswechsel die Investitionen in berufliche Bildung zu verlieren, da spezifische Fähigkeiten und Zertifikate möglicherweise nicht in den neuen Beruf übertragen werden können. Dies kann wiederum zu schlechteren Erwerbsaussichten führen.

Für Arbeitslose, die Arbeitslosengeld oder Sozialhilfe beziehen, kann dies besonders einschneidend sein, da sie durch die Arbeitsagenturen mitunter gezwungen werden können eine Arbeit aufzunehmen, obwohl die Stelle nicht zu ihren Qualifikationen passt. Befunde zeigen, dass großzügigere wohlfahrtsstaatliche Unterstützung die Chancen auf eine gut passende Arbeitsstelle mit weniger nachteiligen sozioökonomischen Folgen erhöht. In Deutschland wurden 2005 die wohlfahrtsstaatlichen Regelungen verschärft, so dass Leistungsempfänger nun jede Arbeit annehmen müssen, die ihnen von der Arbeitsagentur angeboten wird, auch dann, wenn sie nicht im ursprünglichen Berufsfeld ist ( $\$ 10$ SGB II).

Der Artikel betrachtet daher die folgenden Forschungsfragen:

- Welchen Einfluss hat ein Berufswechsel auf den sozioökomischen Status bei Wiederbeschäftigung nach einer Unterbrechung durch Arbeitslosigkeit?

- In wie weit mediiert berufliche Bildung diesen Prozess?

Um diese Fragen empirische untersuchen zu können, wird ein Auszug von erwerbstätigen und arbeitslosen Personen aus der Panelstudie „Arbeitsmarkt und soziale Sicherung“ (PASS) verwendet, welche vom Institut für Arbeitsmarktund Berufsforschung durchgeführt wird. Berufswechsel werden mit Hilfe eines Konzepts gemessen, dass Berufe in Segmente klassifiziert, innerhalb derer eine hohe Übertragbarkeit von Fähigkeiten gegeben ist. Die sozioökonomischen Folgen werden über den International Socio Economic Index (ISEI) gemessen. Dabei handelt es sich um ein latentes Maß der Übersetzung von Bildung in Einkommen, das jeden spezifischen Beruf charakterisiert.

Es wird argumentiert, dass bei gegebener Arbeitslosigkeit ein Wechsel des Berufsfelds vermutlich zu Verlusten im sozioökonomischen Status führt. Der Druck wieder in den Arbeitsmarkt zurückzukehren, könnte die Betroffen dazu zwingen, eine Erwerbstätigkeit aufzunehmen, obwohl das vorherige, berufspezifische Humankapital nicht in den neuen Beruf übertragen werden kann. Dadurch können sich schlechtere Berufsaussichten ergeben. Es wird außerdem angenommen, dass die nachteiligen Folgen von Berufswechseln gravierender sind, je höher der Grad an beruflicher Bildung der jeweiligen Person ist.

Die multivariaten Analysen zeigen, dass sich Berufswechsel in der Tat negativ auf den sozioökonomische Status in der neuen Arbeitsstellen auswirken, wenn sie bei Personen eintreten, die in der letzten Panelbefragungswelle arbeitslos waren. Dieser Effekt ist signifikant stärker, als der für Berufswechsel von Personen die in der letzten Welle erwerbstätig waren. Auch wenn die Befundlage weniger eindeutig ist zeigt sich auch, dass der Verlust von berufsspezifischem Humankapital für Personen mit einem höheren Grad an beruflicher Bildung noch problematischer ist.

Diese Befunde sollten beachtet werden, wenn Arbeitslose mit strengen Wiedereingliederungsmaßnahmen konfrontiert werden. Auch wenn diese helfen mögen die Kosten für wohlfahrtsstaatliche Leistungen zu reduzieren und die Betroffen möglichst schnell wieder in Arbeit zu bringen, könnten sie gleichzeitig den sozioökonomischen Status nach dem Beginn der Wiederbeschäftigung beeinträchtigen. Die vorliegenden Ergebnisse deuten darauf - zumindest für die Situation direkt nach dem Wiedereinstieg - hin. Sie unterstützen somit die Einschätzung, dass es vorteilhaft sein kann, es Arbeitslosen zu ermöglichen nach einer gut passenden Arbeitsstelle zu suchen, selbst wenn es bedeutet, dass sie länger von staatlichen Transferleistungen abhängig sind. Ein Verlust von berufsspezifischem Humankapital sollte vermieden werden, um die Betroffenen vor einem sozioökonomischen Abstieg zu schützen. Dies erscheint auch vor dem Hintergrund eines drohenden Fachkräftemangels in einigen Bereichen der deutschen Wirtschaft sinnvoll. 


\section{Appendix}

Tab. 3 Full regression model of ISEI change

\begin{tabular}{|c|c|c|c|c|}
\hline & \multicolumn{2}{|l|}{ Coefficient } & \multicolumn{2}{|c|}{$\begin{array}{l}\text { Interaction with occupationa } \\
\text { change }\end{array}$} \\
\hline & Point est. & Std. err. & Point est. & Std. err. \\
\hline \multicolumn{5}{|l|}{ Covariates } \\
\hline Occupational change & -1.324 & 0.755 & & \\
\hline Employed in last wave & Ref. & & & \\
\hline Unemployed $<=12$ months in last wave & 1.023 & 1.310 & -0.182 & 1.894 \\
\hline Unemployed $>12$ months in last wave & -3.336 & 1.388 & 2.704 & 1.732 \\
\hline Other status in last wave & -0.007 & 1.005 & 0.198 & 1.603 \\
\hline No vocational training & Ref. & & & \\
\hline Basic level of vocational training & 0.166 & 0.291 & 3.115 & 0.791 \\
\hline High level of vocational training & 0.932 & 0.364 & 1.182 & 0.989 \\
\hline Unempl. $<=12 \times$ Basic voc. training & -0.579 & 1.400 & -5.716 & 1.462 \\
\hline Unempl. $<=12 \times$ High voc. training & 3.793 & 2.047 & -2.310 & 2.274 \\
\hline Unempl. $>12 \times$ Basic voc. training & 1.354 & 1.484 & -4.018 & 1.154 \\
\hline Unempl. $>12 \times$ High voc. training & 5.021 & 1.860 & -4.177 & 1.645 \\
\hline Other status $\times$ Basic voc. training & 0.681 & 1.011 & -6.994 & 1.371 \\
\hline Other status $\times$ High voc. training & 2.123 & 1.309 & -1.224 & 1.746 \\
\hline No or basic schooling & Ref. & & & \\
\hline Intermediate level schooling & 0.319 & 0.237 & -2.273 & 0.686 \\
\hline High level of schooling & 0.419 & 0.288 & -0.403 & 0.835 \\
\hline Unempl. $<=12 \times$ Interm. schooling & -1.126 & 1.168 & 2.698 & 1.246 \\
\hline Unempl. $<=12 \times$ High schooling & -2.481 & 1.567 & 1.529 & 1.904 \\
\hline Unempl. $>12 \times$ Interm. schooling & 0.923 & 1.218 & 2.355 & 1.031 \\
\hline Unempl. $>12 \times$ High schooling & 2.571 & 1.710 & 1.569 & 1.416 \\
\hline Other status $\times$ Interm. schooling & 0.111 & 0.954 & 3.707 & 1.223 \\
\hline Other status $\times$ High schooling & -0.870 & 1.114 & 8.904 & 1.383 \\
\hline Unemployment benefit II receipt & 0.338 & 0.224 & & \\
\hline Single man, no children & Ref. & & & \\
\hline Single woman, no children & 0.073 & 0.332 & & \\
\hline Man with partner, no children & -0.224 & 0.299 & & \\
\hline Woman with partner, no children & -0.212 & 0.328 & & \\
\hline Man with partner and children & -0.134 & 0.271 & & \\
\hline Woman with partner and children & -0.380 & 0.302 & & \\
\hline Single father & -0.789 & 0.786 & & \\
\hline Single mother & -0.754 & 0.347 & & \\
\hline Age (centred) & -0.008 & 0.009 & -0.099 & 0.018 \\
\hline Age, squared & 0.001 & 0.001 & & \\
\hline Migration background & -0.328 & 0.226 & & \\
\hline Resident in eastern part of Germany & -0.277 & 0.192 & & \\
\hline \multicolumn{5}{|l|}{ Occupational segment of original job } \\
\hline "Green" occupations & 3.006 & 0.529 & & \\
\hline Mining and chemicals & 1.312 & 0.540 & & \\
\hline Glass, ceramics and paper & -0.452 & 0.885 & & \\
\hline Textile and leather & 0.018 & 0.559 & & \\
\hline Metal workers & 1.417 & 0.348 & & \\
\hline
\end{tabular}


Dependent variable: change of ISEI score; Random intercept linear regression model

$N=10,670$; Groups $=5,584$;

$R^{2}:$ overall $=0.0364$,

between $=0.0496$,

within $=0.0521$

$\sigma_{\nu}=4.965 ; \sigma_{\epsilon}=4.409 ; \rho=$ 0.559

Source: PASS Scientific Use File 2006-2011 V1, own calculations

\begin{tabular}{lllll}
\hline & Coefficient & & & $\begin{array}{l}\text { Interaction with occupational } \\
\text { change }\end{array}$ \\
\cline { 2 - 3 } Electrical occupations & Point est. & Std. err. & & Point est. \\
Wood & 0.120 & 0.395 & \\
Construction & 0.689 & 0.713 & \\
Food service and catering & 1.462 & 0.405 \\
Warehouse and transport & 1.032 & 0.379 & \\
Sales and bank & 1.587 & 0.320 & \\
Office clerks & -0.364 & 0.276 & \\
Protective services and security & Ref. & & \\
Social workers & 0.216 & 0.390 & \\
Health occupations & 1.896 & 0.339 & \\
Medical doctors & 1.116 & 0.367 & \\
Teachers & -0.935 & 0.980 & \\
Artists & -1.177 & 0.423 & \\
Sciences & -1.093 & 0.629 & \\
Humanities & -0.574 & 1.175 \\
Other occupations & -2.756 & 0.689 \\
Wave 3 & 2.797 & 0.554 \\
Wave 4 & Ref. & & \\
Wave 5 & 0.202 & 0.115 & \\
Constant & 0.141 & 0.119 & \\
\hline
\end{tabular}

\section{References}

Abraham, M., Damelang, A., Schulz, F.: Wie strukturieren Berufe Arbeitsmarktprozesse? Eine institutionentheoretische Skizze. LASER Discussion Paper 55. Labor and Socio-Economic Research Center-University Erlangen-Nürnberg, Nürnberg (2011)

Allison, P.D.: Change scores as dependent variables in regression analysis. Sociol. Method. 20, 93-114 (1990)

Allmendinger, J.: Educational systems and labor market outcomes. Eur. Sociol. Rev. 5, 401-405 (1989)

Becker, G.S.: Human Capital. A Theoretical and Empirical Analysis with Special Reference to Education, 3rd edn. University of Chicago Press, Chicago (1993)

Bender, S., Dustmann, C., Margolis, D., Meghir, C.: Worker displacement in France and Germany. In: Kuhn, P.J. (ed.) Losing Work, Moving on. International Perspectives on Worker Displacement, pp. 375-470. Upjohn Institute for Employment Research, Kalamazoo (2002)

Berg, M., Cramer, R., Dickmann, C., Gilberg, R., Jesske, B., Kleudgen, M., Bethmann, A., Fuchs, B., Trappmann, M., Wurdack, A.: Codebuch und Dokumentation des Panel Arbeitsmarkt und soziale Sicherung (PASS). Datenreport Welle 5. FDZ Datenreport 6/2012. Institute for Employment Research, Nürnberg (2012)

Blossfeld, H.P., Hofmeister, H.: Globalization, Uncertainty and Women's Careers: An International Comparison. Edward Elgar, Cheltenham (2006)

Blossfeld, H.P., Mills, M., Bernardi, F.: Globalization, Uncertainty and Men's Careers: An International Comparison. Edward Elgar, Cheltenham (2006)
Burda, M.C., Mertens, A.: Estimating wage losses of displaced workers in Germany. Labour Econ. 8, 15-41 (2001)

Demszky von der Hagen, A., Voß, G.G.: Beruf und Profession. In: Böhle, F., Voß, G.G., Wachtler, G. (eds.) Handbuch Arbeitssoziologie, pp. 751-803. VS Verlag für Sozialwissenschaften, Wiesbaden (2010)

DiPrete, T.A., De Graaf, P.M., Luijkx, R., Tåhlin, M., Blossfeld, H.P.: Collectivist versus individualist mobility regimes? Structural change and job mobility in four countries. Am. J. Sociol. 103, 318-358 (1997)

Eichhorst, W., Grienberger-Zingerle, M., Konle-Seidl, R.: Activating labor market and social policies in Germany: from status protection to basic income support. Ger. Policy Stud. 6, 65-106 (2010)

Fallick, B.C.: A review of the recent empirical literature on displaced workers. Ind. Labor Relat. Rev. 50, 5-16 (1996)

Fitzenberger, B., Spitz-Oener, A.: Die Anatomie des Berufswechsels: eine empirische Bestandsaufnahme auf Basis der BIBB/IABDaten 1998/1999. ZEW Discussion Paper No. 04-05. Centre for European Economic Research, Mannheim (2004)

Gangl, M.: Institutions and the structure of labour market matching in the United States and West Germany. Eur. Sociol. Rev. 20, 171187 (2004a)

Gangl, M.: Welfare states and the scar effects of unemployment: a comparative analysis of the United States and West Germany. Am. J. Sociol. 109, 1319-1364 (2004b)

Gangl, M.: Scar effects of unemployment: an assessment of institutional complementaries. Am. Sociol. Rev. 71, 986-1013 (2006)

Ganzeboom, H.B.G., De Graaf, P.M., Treiman, D.J.: A standard international socio-economic index of occupational status. Soc. Sci. Res. 21, 1-56 (1992)

Gibbons, R., Katz, L.F.: Layoffs and lemons. J. Labor Econ. 9, 351$380(1991)$ 
Gregory, M., Jukes, R.: Unemployment and subsequent earnings: estimating scarring among British men 1984-1994. Econ. J. 111, 607-625 (2001)

Halaby, C.N.: Action and information in the job mobility process: the search decision. Am. Sociol. Rev. 53, 9-25 (1988)

Hinz, T., Abraham, M.: Theorien des Arbeitsmarktes: ein Überblick. In: Abraham, M., Hinz, T. (eds.) Arbeitsmarktsoziologie. Probleme, Theorien, empirische Befunde, 2nd edn., pp. 17-68. VS Verlag für Sozialwissenschaften, Wiesbaden (2008)

Kuhn, P.J. (ed.): Losing Work, Moving on. International Perspectives on Worker Displacement. Upjohn Institute for Employment Research, Kalamazoo (2002)

Kupka, P.: Berufskonzept und Berufsforschung - soziologische Perspektiven. In: Jacob, M., Kupka, P. (eds.) Perspektiven des Berufskonzepts - die Bedeutung des Berufs für Ausbildung und Arbeitsmarkt. Beiträge zur Arbeitsmarkt- und Berufsforschung BeitrAB, vol. 297, pp. 17-38. Institute for Employment Research, Nürnberg (2005)

Kurtz, T.: Berufssoziologie. Einsichten. Transcript, Bielefeld (2002)

Lockwood, B.: Information externalities in the labour market and the duration of unemployment. Rev. Econ. Stud. 58, 733-753 (1991)

Logan, J.A.: Opportunity and choice in socially structured labor markets. Am. J. Sociol. 102, 114-160 (1996)

Longhi, S., Brynin, M.: Occupational change in Britain and Germany. Labour Econ. 17, 655-666 (2010)

Matthes, B., Burkert, C., Biersack, W.: Berufssegmente. Eine empirisch fundierte Neuabgrenzung vergleichbarer beruflicher Einheiten. IAB-Discussion Paper 35/2008. Institute for Employment Research, Nürnberg (2008)

Nisic, N., Trübswetter, P.: Berufswechsler in Deutschland und Großbritannien. Lohnentwicklung 1994-2008. IAB-Kurzbericht 1/2012. Institute for Employment Research, Nürnberg (2012)

Pissarides, C.A.: Loss of skill during unemployment and the persistence of employment shocks. Q. J. Econ. 107, 1371-1391 (1992)

Pongratz, H.J., Voß, G.G.: Typisch Arbeitskraftunternehmer? Befunde der empirischen Arbeitsforschung. Edition sigma, Berlin (2004)

Schmelzer, P.: Unemployment and occupational mobility at the beginning of employment career in Germany and the UK. IAB- discussion paper 25/2011. Institute for Employment Research, Nürnberg (2011)

Schmelzer, P.: The consequences of job mobility for future earnings in early working life in Germany-placing indirect and direct job mobility into institutional context. Eur. Sociol. Rev. 28, 82-95 (2012)

Schmieder, J.F., von Wachter, T., Bender, S.: The long-term impact of job displacement in Germany during the 1982 recession on earnings, income, and employment. IAB-Discussion Paper 1/2010, Institute for Employment Research, Nürnberg (2010)

Skrondal, A., Rabe-Hesketh, S.: Generalized Latent Variable Modeling. Multilevel, Longitudinal and Structural Equation Models. Chapman \& Hall/CRC, Boca Raton (2004)

Soskice, D.: Divergent production regimes: coordinated and uncoordinated market economies in the 1980s and 1990s. In: Kitschelt, H., Lange, P., Marks, G., Stephens, J.D. (eds.) Continuity and Change in Contemporary Capitalism. Cambridge Studies in Comparative Politics, pp. 101-134. Cambridge University Press, Cambridge (1999)

Spence, M.: Signaling in retrospect and the informational structure of markets. Am. Econ. Rev. 92, 434-459 (2002)

Stewart, M.B.: The interrelated dynamics of unemployment and lowwage employment. J. Appl. Econ. 22, 511-531 (2007)

Uhlendorff, A.: From no pay to low pay and back again? A multi-state model of low pay dynamics. IZA discussion paper 2482. Institute for the study of Labor, Bonn (2006)

Arne Bethmann received a Master's degree in Social Sciences from Friedrich-Alexander-Unversität Erlangen- Nürnberg in 2007, and also finished his $\mathrm{PhD}$ there in 2013. Since 2007 he is a researcher at the Institute for Employment Research, Nuremberg, and started working on the Panel Study "Labour Market and Social Security" in 2008. His main research interests are occupational mobility, welfare, and family research. 